This is an Accepted Manuscript of a book chapter published by Routledge in The Routledge Companion to Literature and Human Rights on 06/08/16 available online: https://www.routledge.com/The-Routledge-Companion-to-Literature-and-HumanRights/McClennen-Schultheis-Moore/p/book/9780415736411 
The Legible Face of Human Rights in Autobiographically Based Fiction

\author{
Meg Jensen
}

"For memory to be effective on a collective level, it must reach large numbers of people [. . .] it must be accessible." (LaCapra 1998: 139)

In recent years there has been much debate over what constitutes the divide between truth-telling and fiction in autobiographical narratives (Gilmore 2001; Murdock 2003; Lazard et al. 2008; Slater 2012; Maftei 2013). Often such debates involve texts that portray, or claim to portray, familial and/or state-sponsored abuses of human rights. In this essay, I will examine a number of narrative forms, from the traditional restorative Bildungsroman, to non-fiction narratives of suffering in so-called "literatures of captivity" (Grice and Woods 2012), to the more hybrid and potentially problematic form of autobiographically based fictions. I suggest that unlike those forms of life narrative that name themselves as legitimate and truth-based (like memoirs, witness testimony, or survivor accounts) or as restorative through their status as literature (like the Bildungsroman), contemporary narratives of rights violation that draw on both autobiographical facts and the creativity of fiction speak to us in unique, and uniquely moving, ways. Works such as the novels of Julia Alvarez, Jamaica Kincaid, JG Ballard, WG Sebald, Kang Chol-Hwan, Tsitsi Dangarembga and others make accessible, and therefore legible, an important frontier: the borderland between individual grief and cultural mourning, truth and fiction, past and present. 
We may take for granted that many of us concerned with the human condition want literary texts to enable a movement towards, rather than away from, compassion and understanding. We want literature that will "open a discursive space that [. . .] enables the exploration of what, exactly, constitutes human rights" (Grice and Woods 2012: 847). For Joseph Slaughter in Human Rights, Inc., at the cross section of life writing and human rights, the key question is how do various literary forms make human rights "legible" (2007: 7)? Slaughter argues that as the Bildungsroman developed historically alongside human rights law, both became "technologies for making common sense common sensical, for making what is already known effective" (2007: 7). Thus the Bildungsroman makes human rights legible in specific and circumscribed ways, as it constitutes "a novelistic correlative to the socialising project of human rights law" (Slaughter 2007: 41). One of the ways in which the Bildungsroman makes rights legible is by drawing upon the real life suffering of its authors (Buckley 1970). Nevertheless, the formulaic structure of the Bildungsroman demands that despite each writer's very different real life experiences, the lives of their protagonists each follow a similar trajectory. In the traditional Bildungsroman, the narrator/protagonist begins "as a rightless individual and moves towards a socially restorative resolution in which s/he becomes a rights-bearing citizen incorporated into the state" (Slaughter 2007: 41). The authors of these texts have traditionally chosen "to reveal and conceal a considerable fund of autobiographical detail" (Buckley 1970: 94, emphasis added) in their novels. This complex formula of revelation and concealment of "real life" suggests a process of coding and encryption inherent in the Bildungsroman even as it attempts to make the rights struggles of its narrators legible. 
Historically, the power to make persons or property "legible" through mapping, census taking, and naming was part of a "Politics of Measurement" enabling "a high degree of schematic knowledge, control and manipulation" (Scott 1998: 11) over what had been made visible. From the Bildungsroman to the misery memoir to the accounts of suffering offered by human rights campaign appeals, many forms of life writing may equally be said to make rights legible in complex, coded, and possibly manipulative ways.

\section{Prosopopeia and pareidolia}

For Paul de Man, the trope of autobiography was "prosopopeia," the rhetorical function of which is to posit "a voice or face by means of language" aimed at "the giving and taking away of faces, with face and deface, figure, figuration and disfiguration" (1979: 926; 930). It gives face to a name, and in so doing, defaces it. Autobiography is "always privative" in de Man's view, as the face it gives through language is necessarily partial and schematic. But partial and schematic seeing lies at the heart of legibility itself (Scott 1998). Certain forms of knowledge require a "narrowing of vision" that "brings into sharp focus certain limited aspects of an otherwise far more complex and unwieldy reality" (Scott 1998: 11). The advantage of this "tunnel vision" is that it "makes the phenomenon at the center of the field of vision more legible" (Scott 1998: 11). This seemingly contradictory observation can perhaps best be understood through the analogy of pareidolia: the psychological phenomenon in which random stimuli are perceived as significant - such as the everyday experience of seeing faces in inanimate objects. 
In all humankind this face-seeing ability is so finely tuned that we can, with minimum information, ascribe not only a face but a mood to such an object ( $(;)$ or $:$ ).

Evolutionary biologists argue over whether this is an advantage, but the phenomenon parallels the way in which autobiographically based fictions of rights violations and their aftermath might make rights legible. Such hybrid narratives, I posit, open a frontier that gives a schematic but entirely recognisable face to human rights and the legacies of its violations by wielding "sharp focus" on "limited aspects" of "unwieldy reality" (Scott 1998: 11). Readers' very awareness of the marginality of these hybrid texts, their either/or-ness, moreover, makes it pleasurable for them to ascribe significance to elements in the narrative that may or may not be random and imaginary. Through their unique combination as providers of pleasure to readers and challenge to dominant narratives, these texts serve a vital role in the legibility, accessibility, and advancement of human rights.

\section{Sentimental education}

In 1993 Richard Rorty called for widespread access to a "sentimental education" that might "sufficiently acquaint people of different kinds [...] so that they are less tempted to think of those different from themselves as quasi human" (1993: 122-3). Slaughter argues likewise that "the gap between what everyone knows and what everyone should know poses human rights as a question of both literacy and legislation, as much of matter of literature as law" (2007: 3). Literature might bridge this educational gap as a site in which "creative imagination plays an indispensable role in achieving progress within the domain of human rights" (Grice and Woods 2012: 831). Slaughter argues that one literary form, the traditional restorative 
Bildungsroman, makes rights legible in a very specific and limiting way as "the predominant formal literary technology in which social outsiders narrate affirmative claims for inclusion in a regime of rights and responsibilities" (2007: 22). The products of this technology are neither wholly benign nor clearly drawn: "the person that emerges is [...] a persona ficta, an often incoherent, self-contradictory, improbable figure" (Slaughter 2007: 19-20).

If "literary and cultural forms" "constitute and regulate" society (Slaughter 2007: 4), then the normative rights personality imagined by the "mutually enabling fictions" (Slaughter 2007: 4) of human rights law and the Bildungsroman also gives rise to "the rightless and marginal" who lack "what the incorporated citizen-subject enjoys" (Slaughter 2007: 43). Thus the Bildungsroman is "a powerful ally in naturalizing the law's [...] ambiguity and ambivalence" (Slaughter 2007: 44). This incoherence is likewise found in the often ambiguous functions of author, narrator, and reader in non-fictional narratives of human rights violations.

\section{Literatures of captivity}

In non-fictional post-trauma and/or post-conflict narratives such as The Aquariums of Pyongyong (2001) by former North Korean gulag prisoner Kang Chol-Hwan, the reader encounters "life at the limits of humanity" (Grice and Woods 2012: 842). While one might predict that the sharing of such horrors would promote a compassionate connection in the style of Rorty's "sentimental education," much recent work on the reception of "true" rights abuse narratives suggests otherwise. One aftermath of traumatic experience is that narrative tone of works like The Aquariums 
"is often oddly measured and virtually devoid of emotion" (Grice and Woods 2012: 842). After sharing his terrifying experiences, Kang tells the reader simply, "From a human rights perspective, my case was shocking" (Chol-Hwan 2001: xxiv).

Kang's tone is not unusual. In many post-trauma autobiographies, graphic details of physical abuse are used to "speak for" the traumatized author/victim, but often in a flattened narrative voice that lists atrocities without commenting upon them (Douglas 2010). Moreover, this recounting of abuse does not tend to evoke lasting empathy in readers (Douglas 2010: 150). Whereas the victim/narrators of these accounts might hope to elicit compassion or even political action, their readers by and large want detachment for themselves and closure for the narrator: "resilient autobiographies" are the most commercially successful (Douglas 2010: 150-69).

Grice and Woods claim that non-fiction "narratives of captivity" extend "the boundaries of victimhood" (2012: 847), thus making legible the distant suffering of others. Nevertheless, these narratives are often "heavily mediated" (Grice and Woods 2012: 844), whether by the victim's need to conceal and/or collaborate with rights workers and translators, etc. Such mediations "should not - indeed cannot - be assumed" to be "either transparent or value-neutral" (Grice and Woods 2012: 844). But while Grice and Woods are quick to counter that "these factors" should not necessarily blunt "the political dissonance" (2007: 844) of such texts, their status as agents of compassion is called into question by a number of recent studies (Douglas 2010; Seu 2010).

\section{Doing denial}


In her studies of audience reactions to fundraising appeals by Amnesty International, Irene Bruna Seu demonstrates that so-called "compassion fatigue" is the result of widespread awareness of external mediations in victims' narratives in the service of fundraising (2010). Seu encountered what she called "a striking mismatch between campaigners' intentions and audiences' reception of appeals, in that participants positioned themselves as critical and discerning consumers rather than moral agents" (2010: 444). Because of the perceived "intractable connection between Amnesty campaigns and money," the participants tended to read to the appeals as "openly cynical, mechanistic and manipulative" (Seu 2010: 444). As one of the participants put it, "We give you the horror story; now give us your money" (Seu 2010: 444-45). For a large number of participants, the suffering of the rights abuse victim in these appeals was made illegible by the very mechanism that sought to raise aid and awareness. Indeed, several stated that such appeals left them feeling that they as consumers were "victims in need of protection" (Seu 2010: 449) from the manipulations of Amnesty's marketing material. If the Bildungsroman offers a limiting and incoherent view of what constitutes rights, and non-fictional accounts of suffering such as rights campaigns and "literatures of captivity" are likewise illegible to fatigued and consumerist readerships, is there a narrative space that better enables understanding and compassion?

\section{Redescription and mimesis}

Paul Ricoeur used the term "redescription" to suggest that although narrative cannot directly reference the world outside the text, it can help us see it in a new way (1985). 
One of the ways in which literature engages in redescription is through literary personification (Miller 1990: 5). Slaughter draws an analogy between this literary process and a social one he terms "incorporation" "that configures the human person with individuality (a name and a face) and sociality (a voice)" (2007: 22). Both personification and incorporation are illusions that appear to enable the voiceless to be heard and the faceless made visible via a recognizable (though virtual) form, which in turn supplies that incorporated fictive figure with both legibility and agency. This is where the analogy of pareidolia is helpful. The phenomenon in which a vague stimulus is perceived as significant is also a process whereby the unfamiliar (a rock, a few lines of ink) appears to be not only familiar (a human face), but also intimate (we can read its mood $:)$. This intimacy is of course an illusion. The word itself is derived from para, meaning "faulty," "wrong," or "instead of" and eidolon, meaning "image, form or shape." At the same time as we perceive this "instead of" face, that is, we know it to be "faulty" (we never believe that the rock face is a human face). Indeed, it is the knowledge of this illusory quality that endows the reading of the image with such powerful pleasure (we cannot help but smile (:)).

In pareidolia, what is legible as an emoting face challenges our understanding of how empathy and intimate recognition are evoked. Rather than blurring our vision or dulling our interest, the simplification of the image and its ironing out of "complex and unwieldy reality" makes the emotive face both "more legible" and a "selective reality" (Scott 1998: 11). Likewise, the false faces we recognise in hybridautobiographical narratives of rights violations are limited and schematic but generate familiarity and intimacy nevertheless. In an inversion of the autobiographical pact (Lejeune 2001: 21), such texts state that the identity of the narrator may or may 
not coincide with the name on the front of the text, and that the events therein may or may not have occurred. Rather than the pareideolic effect of this partial vision being emotionally distancing, it is precisely their semi-fictive distance that enables the reallife suffering recounted in their pages to be heard.

\section{Mimesis}

The reason that the recognition and empathy evoked in such texts matters is that there is a cultural need for the public sharing of traumatic events and their aftermath (Huyssen 2003), particularly when those experiences are the result of widespread violations of human rights. Grice and Woods refer to this sharing as extending "the boundaries of victimhood" (2012: 838) and the spaces in which this sharing occurs may be related to Pierre Nora's formulation of "lieux dé memoire." Lieux dé memoire or realms of memory are visual, oral, and/or textual spaces that generate forms of knowledge about the relations between truth, memory, and memorial (Nora, 1996: 1419). Such "lieux- places, sites," represent the "intent to remember;" moreover, they "have no referents in reality; or rather - they are their own referents - pure signs [...] a circle within which everything counts, everything is symbolic, everything is significant" (Nora 1996: 14-19). Like our paraideolic smiley face (-)), Nora's circles within which everything counts refer not to an event or thing, but rather to ideas about the thing, and "beyond simply exercising memory, they interrogate it"(1996: 19). Autobiographically based fictions that recount human rights violations and their aftermath enable just such interrogations of memory to take place in a space whose form is ambiguous yet recognisable. 
Adorno argued that experience expressed as form "becomes the voice of human beings between whom the barriers have fallen" (1993: 54). Huyssen's reading of Spiegelman's autobiographical graphic novel Maus, builds on this idea of falling barriers and on Adorno's Bilderverbot (Adorno 1944) - the prohibition of graven images - which Adorno famously employed to proclaim that "poetry after Auschwitz is barbaric" (1967: 34). Using Maus as an example, Huyssen demonstrates that hybrid autobiographical texts are uniquely able to respect and interrogate the past by employing a range of aesthetic and mimetic techniques aimed at avoiding "authentic" representation.

For Huyssen, "it is precisely this multivalence of mimesis . . that makes the concept productive for contemporary debates about memory, trauma, and representation in the public realm" (2003: 123). Texts such as Maus, that is, make human rights and rights transgressions legible by enacting "a project of mimetically approximating historical and personal trauma" in which past and present "are knotted together" (Huyssen 2003: 127). Nevertheless, Huyssen also notes that there are "dimensions to mimesis that lie outside linguistic communication and that are locked in silences, repressions, gestures and habits [.. .] a becoming or making similar, a movement toward, never a reaching of, a goal ...” (2003: 127). Thus the incomplete, fragmentary mimetic gestures of autobiographically based fictions fight against the tendency towards what Huyssen calls the "narcissistic delusions of grandeur" and "imaginary wholeness" (2003: 39) implicit in other cultural monuments to suffering from Bildungsromane to memoirs to war memorials. Indeed, in such hybrid texts the approximated, incomplete "false face" on offer makes legible not only the violent events of the past, but their ongoing presence, the aftermath of those events in the here and now. 
The function of mimesis in a text like Maus is "not to document but to stress the unassimilability of traumatic memory" (Huyssen 2003: 127). "Drawing the story [. . ] as an animal comic," Huyssen notes, "allows Spiegelman to escape from the terror of memory [. . .] while mimetically re-enacting it" (2003: 128). Like the rock face or the smiley emoticon, this aestheticized, schematic, and "approximating" approach to narrating rights violations makes those rights legible in complex and even contradictory ways. As Spiegelman himself has made clear: "I didn't want people to get too interested in the drawings. I wanted them to be there, but the story operates somewhere else [. . .] between the words and the idea that's in the pictures" (quoted in Brown 1988: 103). Like the "false face" of the emoticon, the mice of Spiegelman's tale are recognisably human and non-human, simultaneously us and not-us, and the empathy they evoke is a product of this either-or-ness. It is evoked by the "story" that "operates somewhere else": the story that the reader recognises as both true and too terrible to be told. As Speigelman notes, by "not focusing" the reader "too hard on these people you're forced back into your role as reader rather than looker" (Brown 1998: 103). Through its form, "Maus 'preserves the legitimacy of the image' [. . .] in the faithful pursuit of its prohibition" (Huyssen 2003: 131). By presenting a simplified and "selective reality" (Scott 1998: 11), Spiegelman makes legible aspects of atrocity and its ongoing aftermath to a whole new generation of readers (LaCapra 1998: 140).

\section{Agency and authority}

The texts of many writers who bear witness to traumatic violations of their rights are often inflected by complex and contradictory representations of agency and authority 
(Henke 1998; Caruth 1995; Caruth 1996; LaCapra 1998; La Capra 2000; Gilmore 2001). Whereas Huyssen examines evidence of such inflections in the voices and faces of Spiegelman's work, Slaughter (2012: 229) takes note of the challenges to the traditional restorative Bildungsoman of a novel that attempts to represent both rights violations and their aftermath: Tsitsi Dangarembga's Nervous Conditions (1988). As Slaughter notes, this "partially autobiographical Bildungsroman explores inconsistencies and contradictions of the colonial systems of Rhodesian society and culture" (2007: 228). The novel begins somewhat shockingly; "I was not sorry when my brother died," Dangarembga writes, before turning to a far more traditional trajectory: "I shall . . . begin by recalling the facts as I remember them that led up to my brother's death, the events that put me in a position to write this account" (1988: 1). Here we find the "implicit narrative contract of the first person Bildungsroman, which promises to tell the story of how the narrator became a narrator" (Slaughter 2007: 229). By the conclusion of the novel, the narrator "reneges" on this contract, announcing, "Something in my mind began to assert itself, to question things and refuse to be brainwashed [. . .] It was a long and painful process for me [. . .] whose events stretched over many years and would fill another volume" (Dangarembga 1988: 204). Slaughter reads the ambiguous conclusion of this novel as "a significant ellipsis" whose meaning arises from the way in which it "undoes the seamlessness and formal certainty expected" (2012: 230). Like Spiegelman's mice and the false face of pareidolia, this conclusion makes rights violations legible by pointing at other ongoing, untold, or untellable stories, at traumatic experiences and their aftermath that cannot be contained within the formal certainty and closure of the Bildungsroman, the witness statement or the memoir precisely because they continue in real time outside the text. Hybrid texts like these challenge us, in Spiegelman's terms, to be "readers" 
rather than "lookers," to read between the lines of the partial and schematic to see the bigger picture.

Similar challenges to wholeness, seamlessness and "formal certainty" can be found in any number of autobiographically based fictions that interrogate past rights violations and their ongoing impact (Jensen 2014). Readers can bring a consumerist, cynical eye to narratives of suffering. The pareideolic face of autobiographically based fictions, however, creates a space in which rights are made not only legible but moving. It may therefore also be a space in which social and political actions are initiated. As a frontier between "legal" and "extra-legal," "witnessing" and "illusion," "face" and "not-face," such texts adhere to and disrupt narrative authority in equal, and therefore contradictory, measure. If autobiography is "always privative" (de Man 1979: 930) autobiographically based fictions are also always generative, provoking recognition and the imaginative space for empathy, and ultimately, agency, for both the facemaker and their audience. 
References

Adorno, T. ([1944] 1983) "Elements of Anti-Semitism," in T. Adorno and M.

Horkheimer (eds) Dialectic of Enlightenment, trans. J. Cumming, London: Verso.

-- .(1993) “On Lyric Poetry and Society,” in, R. Tiedemann (ed.) Notes to Literature: volume one, trans. S. Weber Nicholson, New York: Columbia University Press.

-- . (1967) Prisms, 6th edn, trans. S. and S. Weber, Cambridge, MA: MIT Press.

Brown, J. (1988) "Review Essay: of mice and memory," Oral History Review 16 (1): 91-109.

Buckley, J. (1970) “Autobiography in the English Bildungsroman,” in M. Bloomfield (ed.) The Interpretation of Narrative: theory and practice, Cambridge, MA: Harvard University Press.

Caruth, C. (1995) Trauma: explorations in memory, Baltimore: Johns Hopkins University Press.

-- . (1996) Unclaimed Experience: trauma, narrative, and history, Baltimore: Johns Hopkins University Press.

Chol-hwan, K. (2001) The Aquariums of Pyongyang: ten years in the North Korean gulag, trans. P. Rigoulot, New York: Basic Books.

Dangarembga, T. (1988) Nervous Conditions, London: Women's Press.

de Man, P. (1979) “Autobiography as De-Facement,” Modern Language Notes 94 (5): 919-30.

Douglas, K. (2010) Contesting Childhood: autobiography, trauma, and memory, New Brunswick, NJ: Rutgers University Press. 
Gilmore, L. (2001) The Limits of Autobiography, Ithaca, NY: Cornell University Press.

Grice, H. and Woods, T. (2012) "Human rights, human wrongs: literatures of captivity," Textual Practice 26 (5): 829-50.

Henke, S. (1998) Shattered Subjects: trauma and testimony in women's life-writing, Basingstoke: Macmillan.

Huyssen, A. (2003) Present Pasts: urban palimpsests and the politics of memory, Stanford, CA: Stanford University Press.

Jensen, M. (2014) "Post-Traumatic Memory Projects: autobiographical fiction and counter-monuments," Textual Practice 28 (4): 701-25.

LaCapra, D. (1998) "Twas the Night before Christmas: Art Spiegelman and Maus," in History and Memory After Auschwitz, Ithaca, NY: Cornell University Press, pp. 139-79.

-- . (2001) Writing History, Writing Trauma, Baltimore, MD: Johns Hopkins University Press.

Lejeune, P. (1989) On Autobiography, P. J. Eakin (ed.), trans. K. Leary, Minneapolis: University of Minnesota Press.

Murdock, M. (2003) Unreliable Truth: memoir and memory, New York: Seal Press.

Lazar, D. (ed.) (2008) Truth in Nonfiction: essays, Iowa City: University of Iowa Press.

Maftei, M. (2013) The Fiction of Autobiography: reading and writing identity, London: Bloomsbury.

Miller J. H. (1990) Versions of Pygmalion, Cambridge, MA: Harvard University Press. 
Nora, P. (1996) Realms of Memory: The Construction of the French Past, Vol 1,, New York: Columbia University Press.

Ricoeur, P. (1985) Time and Narrative, vol 2., trans. K. McLauglin and D. Pellaver, Chicago: University of Chicago Press.

Rorty, R. (1993) “Human Rights, Rationality and Sentimentality," in S. Shute and S. Hurley (eds) On Human Rights: the Oxford Amnesty lectures 1993, New York: Basic Books,pp. 111-134. .

Scott, J. C. (1998) Seeing Like a State: how certain schemes to improve the human condition have failed, New Haven, CT: Yale University Press.

Seu, I. B. (2010) “'Doing Denial': audience reaction to human rights appeals," Discourse \& Society 21 (4): 438-57.

Slaughter, J. (2007) Human Rights, Inc.: the world novel, narrative form, and international law, New York: Fordham University Press.

Slater, L. (2012) Lying: a metaphorical memoir, New York: Random House. 
Further Reading

Butler, J. (2009) Frames of War: when is life grievable? New York: Verso.

(Considers the media's portrayal of armed conflict and rights violations.)

Edkins, J. (2003) Trauma and the Memory of Politics, Cambridge, MA: Cambridge University Press. (Questions the assumed role of commemorations as reinforcing state and nationhood.)

Felman, S. (2002) The Juridical Unconscious: trials and traumas in the twentieth century, Cambridge, MA: Harvard University Press. (Offers a groundbreaking account of the surprising interaction between trauma and justice.)

Jensen, M. and Jolly, M. (eds) (2014) We Shall Bear Witness': life narratives and human rights, Wisconsin: University of Wisconsin Press. (Conversations and connections between human rights and life writing through an extraordinary international range survivor-writers, scholars, activists, and advocates.)

Whitehead, A. (2004) Trauma Fictions, Edinburgh: Edinburgh University Press. (Explores the literary potential of trauma in a range of contemporary fictions.)

\section{Autobiographically Based Fictions}

Alvarez, J. (1990) How The Garcia Girls Lost their Accents, New York: Algonquin Books.

-- . (1994) In the Time of Butterflies, New York: Algonquin Books.

-- . (1997) Yo! New York: Algonquin Books.

Ballard, J.G. (1984) Empire of the Sun, London: V.Gollancz.

-- . (1991) The Kindness of Women, New York: Farrar Straus \& Giroux.

Kincaid, J. (1985) Annie John, London: Vintage.

-- . (1983) At the Bottom of the River, New York: Farrar Straus \& Giroux. 
-- . (1995) Autobiography of my Mother, New York: Farrar Straus \& Giroux.

-- . (1997) My Brother, New York: Farrar Straus \& Giroux.

Sebald, W.G. (2001) Austerlitz, London: Hamish Hamilton.

-- . (1995) The Rings of Saturn, London: Harvill

-- . (1992) The Emigrants, London: Harvill.

-- . (1999) Vertigo, London: Harvill.

[4265 words] 